\title{
応答スペクトル法による中規模ラチスドームの地震応答評価 \\ RESPONSE EVALUATION OF MEDIUM-SPAN LATTICE DOMES WITH SUBSTRUCTURES USING RESPONSE SPECTRUM ANALYSIS
}

\author{
竹内 徹*1, 小河利行*2, 中川美香*3, 熊谷知彦*4 \\ Toru TAKEUCHI, Toshiyuki OGAWA, Mika NAKAGAWA \\ and Tomohiko KUMAGAI
}

\begin{abstract}
Seismic responses of lattice domes with substructures are known to be very complicate, because of the dome having large numbers of parallel vibration modes, and their amplitude changing drastically along the relationship between domes and substructures. Under limited condition, however, their response characteristics are considered to become relatively simple. In this paper, various shapes of domes are analyzed using response spectrum analyses with CQC method, which is less time-consuming than time-history analyses. The conditions for simplifying the principal modes are made clear through these studies, and their response characteristics are discussed.
\end{abstract}

Keywords : Lattice Domes, Seismic Response Analysis, Response Spectrum Analysis, CQC Method ラチスドーム, 地震応答解析, 応答スペクトル法, $\mathrm{CQC}$ 法

\section{1. 序}

下部構造に支持されたドーム構造に水平地震動が働いた際の応答 性状については, 既に多くの研究がなされており, その性状が明ら かにされつつある。ドーム構造は一般的に, 非常に多くの振動モ一 ドが近接した固有周期において卓越するため,下部構造との関倸に よりその応答が大きく変化し,これを包括的に把握し表現すること は容易ではない。この問題を解決するため, 加藤, 小西ら ${ }^{122) 3) ~ は, ~}$ ドーム部を複数の並列する振動系に置き換え,下部構造振動系と直 列配置することで下部構造付ドームを簡易振動モデルに表現しっこ れを用いた応答評価法を提案している。また,下部構造が塑性化す る場合， 1 次モード支配型の前提で，同モデルを 1 自由度系に縮約 し, 限界状態計算を行う方法についての提案を行っている。一方, 山田4) は, 下部構造付空間構造の応答を評価する前提として, 下部 構造と上部構造の質量比と剛性比または固有周期比が, 上部応答に 与える影響についての基礎的考察を行っている。これら既往の研究 を通じて得られた知見として，以下が挙げられる。

1) 下部構造を含むドームの振動特性において，より少ない振動モ一 ドに有効質量が集中している場合には，応答性状を単純化でき， 静的地震荷重へのモデル化が容易となる。

2)ドーム自身の固有周期带に対し下部構造の固有周期が我離してい る場合には，両者を合成した振動性状は比較的単純化されるが， 下部構造の固有周期がドームの固有周期帯内に位置する場合に
は，その複合振動性状は非常に複雑となる。

3)一般的傾向として,ドームを構成するラチス材の面外㓮性が高い ほど, 卓越する主要なモード数は減少する。例として, 単層ドー ムより複層ドームの方が，有効質量比の和が 90\%以上となるた めの振動モード数は少なくなる傾向がある。

以上の知見を総合すると，ある限られた条件下，即ち，一定以上の 面外剛性を持つラチス材により構成され，下部構造との振動性状が一 定条件を満足するドームでは, 応答性状が比較的単純化され, 静的地 震荷重のモデル化が容易となる仮説が成り立つ。しかしながら, 現在 までの知見において，その範囲が明確になっているとは言い難い。加 藤, 小西らの提案する多質点並列モデルは, より多くの範囲をカバー することが可能であるが, ドーム部の固有值解析を必要とするため, 中小規模の建物に適用する設計法としてはやや煩雑となる。また，下 部構造が塑性化した場合にはその等価剛性が低下するため, 上部構造 周期帯との分離が容易となり，応答性状が単純化できると推察される が，その範囲は未だ明確になっていない。上記範囲を明らかにする ことにより,応答性状が単純化できるドーム構造物の条件が明確化で きることが期待できる。ライズを有するドームでは, 水平入力に対す る鉛直方向の励起も顕著であるため, 上記条件内の応答を整理し, 中 規模ドーム設計用に一般化することは, 空間構造の静的地震荷重の整 理普及のために有意義であると考える。

そこで, 本研究では CQC 法5)を利用して, ドームの面外剛性, 及
*1 東京工業大学理工学研究科建築学尃攻 助教授・博士 (工学)

*2 東京工業大学理工学研究科建築学尃攻 教授. 工博

*3 侏 CRCソリューションズ 修士(工学)

(元 東京工業大学 大学院生)

*4 東京工業大学理工学研究科建築学尃攻 助手. 博士 (工学) （元 東京工業大学 大学院生）
Assoc. Prof., Dept. of Arch. and Building Eng., Tokyo Institute of Technology, Dr. Eng.

Prof., Dept. of Arch. and Building Eng., Tokyo Institute of Technology, Dr. Eng. CRC Solutions Corporation, M. Eng.

(Ex-Graduate Student, Tokyo Institute of Technology)

Research Assoc., Dept. of Arch. and Building Eng., Tokyo Institute of Technology, Dr. Eng.

(Ex-Graduate Student, Tokyo Institute of Technology) 
び下部構造との特性を変化させた多くの下部構造付中規模ドーム構 造についての応答評価を行い,その応答性状と卓越する振動モード との関係を詳細に分析することによって,応答が単純化できるドー ムの条件を明らかにすることを目的とする。CQC 法は，ドーム構 造のような多振動モードが近接する構造物のランダム振動応答を, 応答スペクトル法を用いて評価するうえで, SRSS法より精度が高 く，また時刻歴応答解析より計算時間が短く，応答特性を分析し易 い特徵がある。その精度についてはすでに前報6)7)で検討し，半開 角 $20^{\circ} \sim 40^{\circ}$ の円形ドームにおいて, 有効質量比 $90 \%$ までの振動モ一 ドを用いた CQC 法による合成を行えば，幾何非線形性を考慮した 時刻歷応答解析と同等の応答評価が可能であることを示した。本報 では，その手法を利用し，同様のライズ/スパン比の範囲で下部構 造の無いドームの面外剛性を変化させたモデルについて振動モード を分析し，卓越モードと面外剛性との関係を明らかにする。続い て, 下部構造を付加し, その剛性を変化させたモデルについてパラ メトリックに分析を行い, 振動特性比と卓越モードとの関係を明ら かにする。以上の結果を用い, 卓越モードが限定される中規模ドー ムの応答特性を明らかにし，限定されたモードを使用した応答評価 の精度について検証する。さらに,これを包絡する静的地震荷重の 設定を試み，その精度を検証することにより，今後の設計法整備の ためのデータを提供する。

\section{2. 娭討モデル}

検討モデルは，図 1 及び表 1 に示すようなスパン $L=60 \mathrm{~m}$ の中規 模単層ラチスドームであり, 半開角は $\theta=20^{\circ}, 30^{\circ}, 40^{\circ}$ の 3 種類と する。柱脚はピン支持とし，柱頭とテンションリング間はピン接合 とする。表 2 に部材諸元を示す。以降，地震波入力方向に沿った節 点 $\mathrm{A}, \mathrm{O}, \mathrm{A}^{\prime}$ を通る円弧を稯線と呼ぶ。ドームを構成する部材は全 て円形鋼管とし，固定荷重のみを受ける時の部材応力が，ほぼ一様 になる様設計する。下部構造は,ベースシアー係数 $C_{0}=0.3$ のせん

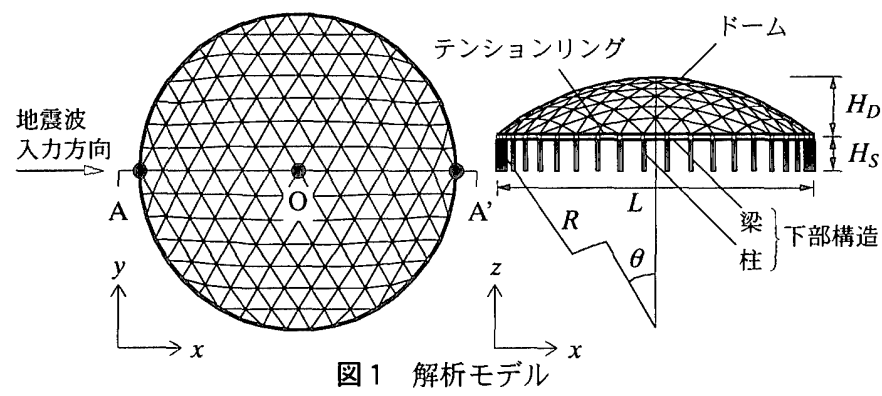

表 1 ドーム形状諸元

\begin{tabular}{|c|c|c|c|}
\hline 半開伤 $\theta$ (deg.) & 20.0 & 30.0 & 40.0 \\
\hline ドームのスパン $L(\mathrm{~cm})$ & \multicolumn{3}{|c|}{6000} \\
\hline ドームの曲率半径 $R(\mathrm{~cm})$ & 8771 & 6000 & 4667 \\
\hline トームのライズ $H_{D}(\mathrm{~cm})$ & 529 & 804 & 1092 \\
\hline 支持挂長さ $H s(\mathrm{~cm})$ & \multicolumn{3}{|c|}{600} \\
\hline 稜楾部材長さ $l(\mathrm{~cm})$ & 510 & 523 & 543 \\
\hline
\end{tabular}

表 2 部材諸元

\begin{tabular}{|c|c|c|c|c|c|}
\hline & \multicolumn{3}{|c|}{ ドーム（稜線） } & \multirow{2}{*}{$\begin{array}{c}\text { テンション } \\
\text { リング }\end{array}$} & \multirow{2}{*}{ 柱 } \\
\hline 半開角 $\theta$ & $20^{\circ}$ & $30^{\circ}$ & $40^{\circ}$ & & \\
\hline 部材細長比 $\lambda$ & $90.6 \sim 93.4$ & $91.8 \sim 93.2$ & $94.9 \sim 95.8$ & 21.2 & 18.9 \\
\hline 外径 $D(\mathrm{~cm})$ & \multicolumn{3}{|c|}{16.52} & 60.96 & 91.44 \\
\hline 厚さ $t(\mathrm{~cm})$ & $0.60 \sim 1.10$ & $0.40 \sim 0.65$ & $0.35 \sim 0.50$ & 1.27 & 1.60 \\
\hline 断面稓 $A\left(\mathrm{~cm}^{2}\right)$ & $30.01 \sim 53.29$ & $20.26 \sim 32.41$ & $17.78 \sim 25.16$ & 238 & 452 \\
\hline 断面二次モーメント $I\left(\mathrm{~cm}^{4}\right)$ & $952 \sim 1592$ & $658 \sim 1020$ & $581 \sim 808$ & 106000 & 456000 \\
\hline ヤング倸数 $E\left(\mathrm{kN} / \mathrm{mm}^{2}\right)$ & \multicolumn{5}{|c|}{206} \\
\hline
\end{tabular}

断力, 及びドーム部の固定荷重相当の軸力に対して弾性範囲とし, 層間変形が $1 / 200$ 以下となる様設計する。固定荷重は, 構造材重量, 仕上げ材重量, 吊り荷重等を考慮し, ドーム部 $1.18 \mathrm{kN} / \mathrm{m}^{2}$, 下部構 造 $0.98 \mathrm{kN} / \mathrm{m}^{2}$, 及びテンションリングの自重とする。

図2に各モデルの卓越する固有モードを示す。有効質量比 $90 \% に$ なるモード数及び卓越モードは，半開角により異なっており，規則 性は見られない。

\section{3. 応答スペクトル法の䧮度}

幾何非線形性を考慮した時刻歴応答解析と応答スペクトル法を比 較し，応答スペクトル法の精度を検討する。減衰は Rayleigh 型と し, 減衰定数は 1 次， 2 次モードで $2 \%$ を仮定する。応答スペクト ル法では，モード間の相関を考慮する CQC法を用いる。CQC法に よる節点 $i$ の最大応答值 $\left|x_{i}\right|$ は下式で表される。

$$
\left|x_{i}\right|=\sqrt{\sum_{s=1}^{N} \sum_{r=1}^{N}\left(\beta_{s} S\left(T_{s}, h_{s}\right)_{s} u_{i s}\right) \rho_{s r}\left(\beta_{r} S\left(T_{r}, h_{r}\right)_{r} u_{i r}\right)}
$$

ここで, $\beta_{s}$ は $s$ 次の刺激係数, $T_{s}$ は $s$ 次の固有周期, $h_{s}$ は $s$ 次の減 衰定数, $S\left(T_{s}, h_{s}\right)_{s}$ は $s$ 次の応答スペクトル, $u_{i s}$ は節点 $i$ の $s$ 次の固有 ベクトル, $\rho_{s r}$ は $s$ 次と $r$ 次との間のモード相関係数である。刺激係 数 $\beta$ 及び固有べクトル $u$ には，固定荷重下の軸力による幾何剛性を 考慮した固有値解析により求めた值を用いる。また, モード相関係 数 $\rho$ は, 地動の継続時間が各次固有周期に比べて充分長く, 地動が ホワイト・ノイズである場合の值であり，文献 5，8，9 で示された (2) (4) 式を用いる。

$$
\begin{aligned}
& \text { 相対変位: } \rho_{s r}=\frac{8 \sqrt{h_{s} h_{r}}\left(h_{s}+\gamma h_{r}\right) \gamma^{3 / 2}}{\left(1-\gamma^{2}\right)^{2}+4 h_{s} h_{r} \gamma\left(1+\gamma^{2}\right)+4\left(h_{s}^{2}+h_{r}^{2}\right) \gamma^{2}} \\
& \text { 相対速度: } \rho_{s r}=\frac{8 \sqrt{h_{s} h_{r}}\left(h_{r}+\gamma h_{s}\right) \gamma^{3 / 2}}{\left(1-\gamma^{2}\right)^{2}+4 h_{s} h_{r} \gamma\left(1+\gamma^{2}\right)+4\left(h_{s}^{2}+h_{r}^{2}\right) \gamma^{2}}
\end{aligned}
$$

絶対加速度

$$
\rho_{s r}=\frac{8 \sqrt{h_{s} h_{r}}\left\{h_{r}+\gamma^{3} h_{s}+4 h_{s} h_{r}\left(h_{r}+h_{s}\right)\right\} \sqrt{\gamma}}{\sqrt{\left(1+4 h_{s}^{2}\right)\left(1+4 h_{r}^{2}\right)}\left\{\left(1-\gamma^{2}\right)^{2}+4 h_{s} h_{r} \gamma\left(1+\gamma^{2}\right)+4\left(h_{s}^{2}+h_{r}^{2}\right) \gamma^{2}\right\}}
$$

ここで, $\gamma$ は $s$ 次と $r$ 次の固有円振動数比 $\omega_{r} / \omega_{s}$ である。入力地震波 は，人工地震波 BCJ-L1，El Centro NS (1940), Taft EW (1952), Hachinohe NS (1968), Kobe JMA NS (1995) とし，最大速度を $25 \mathrm{~cm} / \mathrm{s}$ に基準化して用いる。

図 3は, 時刻歴応答解析結果と有効質量比 $90 \%$ でのCQC法による 応答值を比較したものである。多様な地震波を通じ, 加速度, 変位, 部材応力とも時刻歴応答解析結果とCQC法による応答值は良い対応

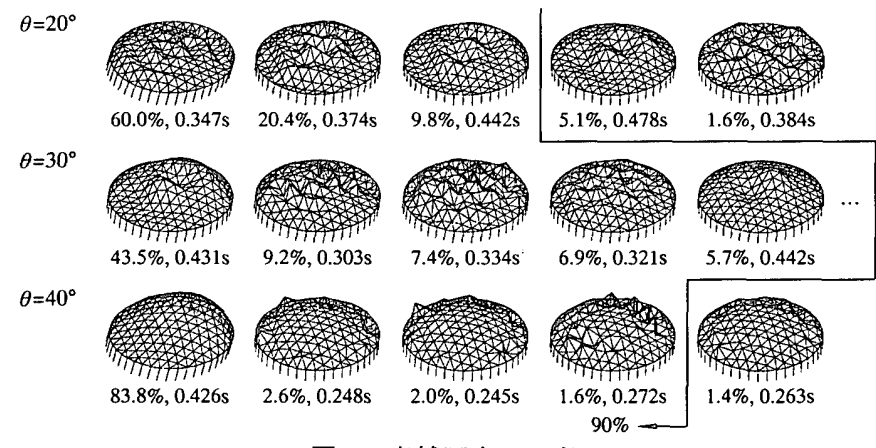

图 2 卓越固有モート 


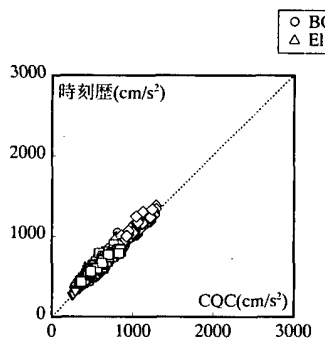

(a1) 水平加速度

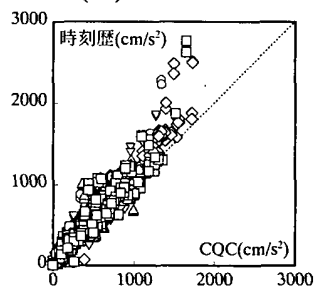

(a2) 鉛直加速度 $\begin{array}{ll}\circ B C J-L 1 & \diamond \\ \triangle \text { El Centro NS } & \nabla \text { Taff EW } \\ & \text { Hachinohe NS }\end{array}$

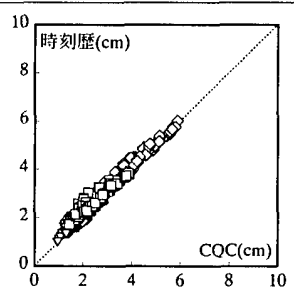

(b1) 水平変位

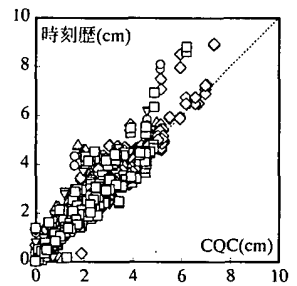

(b2) 鉛直変位

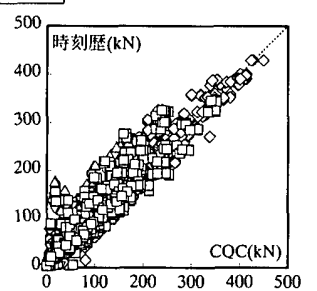

(c1) 軸力

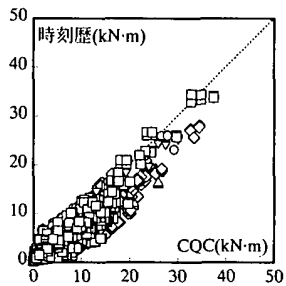

(c2) 曲げモーメント

図 $3 \mathrm{CQC}$ 法の精度

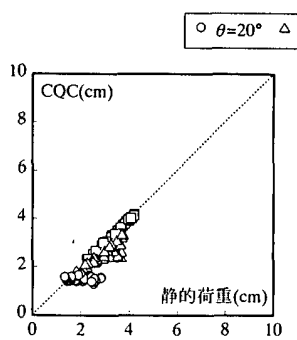

(a1) 水平変位

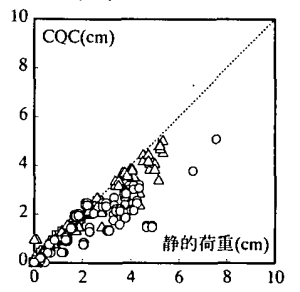

(a2) 鉛直変位

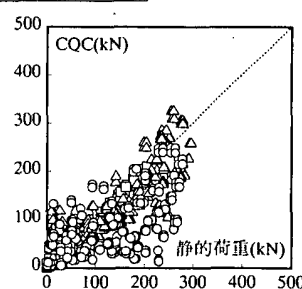

(b1) 軸力

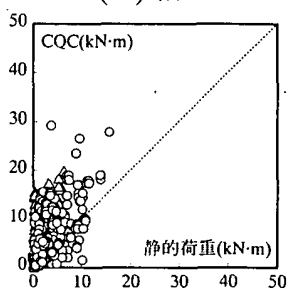

(b2) 曲げモーメント

図 4 最大応答加速度を静的荷重係数とした場合の精度 (BCJ-L1)

を示している。これより，ラチスドームにおいて，ここで扱う応答 の範囲では, 有効質量比 $90 \%$ での CQC 法は, 幾何非線形性を考慮 した時刻歴応答解析と同等の応答評価が可能であると考えられる。

静的地震荷重を設定する手法としては, 最大応答加速度と質量の 積を使用する方法が最も簡便であり，その精度を検証する。図4は， $\mathrm{CQC}$ 法とCQC法による応答加速度と質量の積を静的地震荷重とし て載荷した場合の最大変位及び部材応力を比較したものである。変 位はほぼ対応しているが, 軸力と曲げモーメントは必ずしも良い対 応を示していない。これは, 全節点の加速度, 変位もしくは各部材 応力が，同時刻に最大とならないためである。これより, 最大応答 加速度を静的地震荷重係数として使用した場合, 部材応力の評価に は一定の誤差が伴うことがわかる。

\section{4. デプス/スパン比と卓越モード}

3 章で示した検討モデルは, 有効質量比 $90 \%$ に必要なモード数が 半開角 $\theta=20^{\circ}, 30^{\circ}, 40^{\circ}$ の順に $3,10,4$ モ一ドとなっており, その モード形状もモデルにより大きく異なるため, これらのモデルに対 する静的地震荷重を一般化することは難しい。そこで, ドーム部材 の曲げ剛性を大きくすることにより，ドームの面外剛性が卓越モ一 ドに与える影響を見る。これまでの検討モデルのドーム部のみをテ ンションリングでローラー支持としたモデルをR 1 , 部材の曲げ剛性 を10倍，100倍にしたものをそれぞれR10，R100とする。R10，R100

\section{は表 3 に示すように, 同断面積でデプス/スパン比が $1 / 170,1 / 50$ 程} 度とした複層ラチスドームに相当する。

図 5 に, 半開角 $\theta=30^{\circ}$ の屋根モデルについて, 面外剛性を高くし ていった場合の卓越する固有モードを示す。面外剛性が高くなるに つれ, 有効質量比 $90 \%$ に必要なモード数は減少する。また, R1で は面内変形モードが卓越しているが, 面外㴊性が高くなると面外変 形モードが卓越してくる。図 7 に, 半開角 $\theta=20^{\circ}, 40^{\circ}$ の場合の卓 越モードの傾向を併せて示す。同図より, 半開角に関わらず, 面外 魝性が高くなるにつれて, 有効質量比 $90 \%$ に必要なモード数が $4 \sim 8$ に減少することがわかる。この中には，図6に示すような逆対称 1 波 $(\mathrm{O} 1)$, 逆対称 2 波 (O2), 逆対称 2.5 波 (O2.5), 面内変形 (I) モ一 ドの 4 モードが共通に見られ, 半開角に関わらず,これらのモード で有効質量比 $80 \%$ 以上を占めるようになる。以降, この 4 モード を主要 4 モードと呼ぶ。

以上より, 今回の検討モデルでは, デプス/スパン比 $1 / 50$ 程度に なると, 卓越するモードが主要 4 モードに限定され, 応答性状が比

\begin{tabular}{c|c|c|c|} 
表 3 & デプス / スパン比 $(d / L)$ \\
\hline Model & $\theta=20^{\circ}$ & $\theta=30^{\circ}$ & $\theta=40^{\circ}$ \\
\hline R1 & - & - & $\vdots$ \\
\hline R10 & $1 / 172$ & $1 / 169$ & $1 / 168$ \\
\hline R100 & $1 / 54$ & $1 / 53$ & $1 / 53$ \\
\hline
\end{tabular}
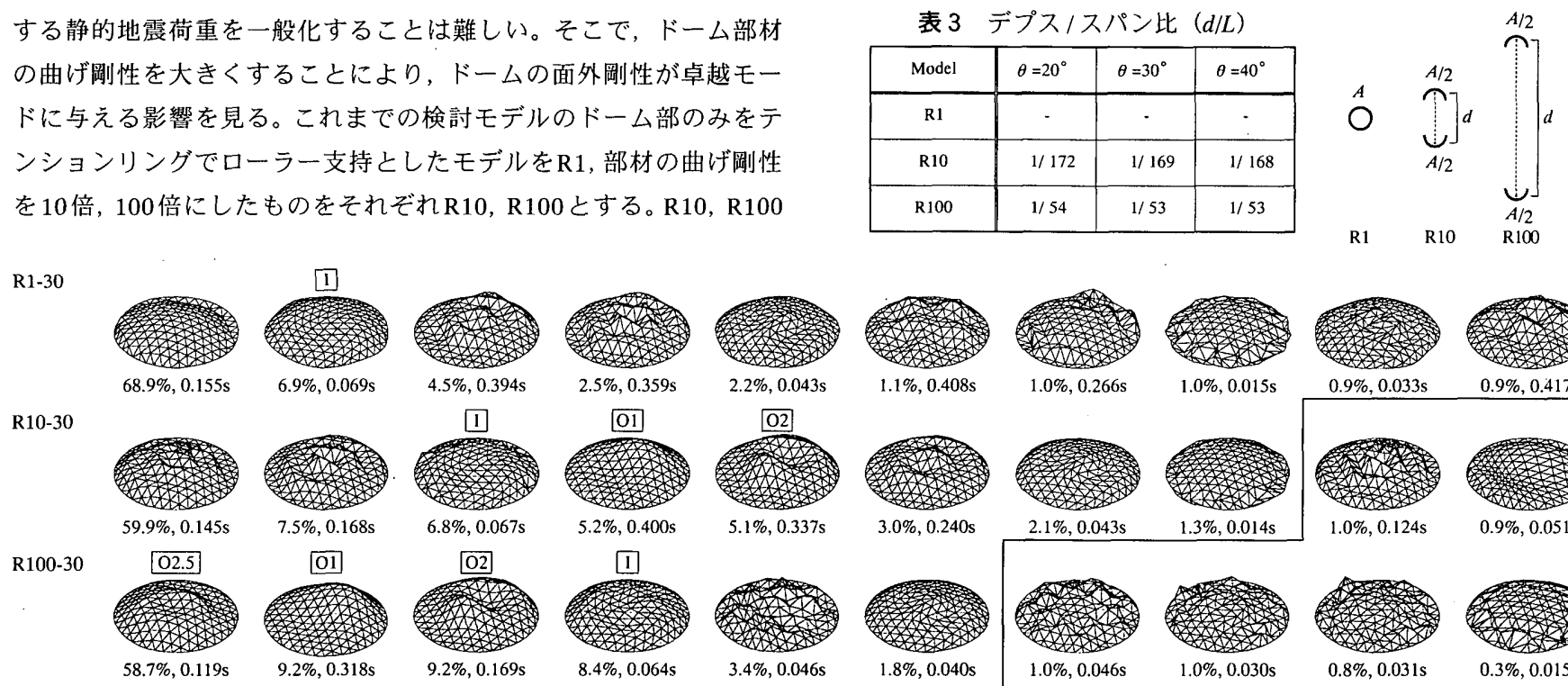

$1.0 \%, 0.266 \mathrm{~s}$

$1.0 \%, 0.015 \mathrm{~s}$
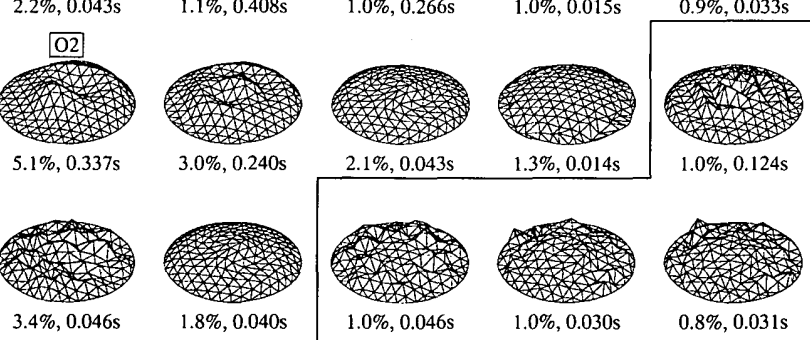

$1.3 \%, 0.014 \mathrm{~s}$

$1.0 \%, 0.124 \mathrm{~s}$

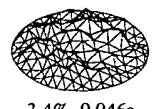

$90 \%$
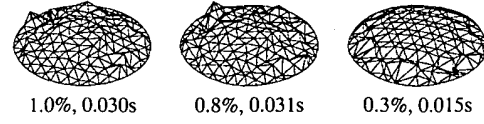

$0.8 \%, 0.031 \mathrm{~s}$

図 5 ドームの面外㓮性と卓越モード（ $\theta=30^{\circ} ）$ 


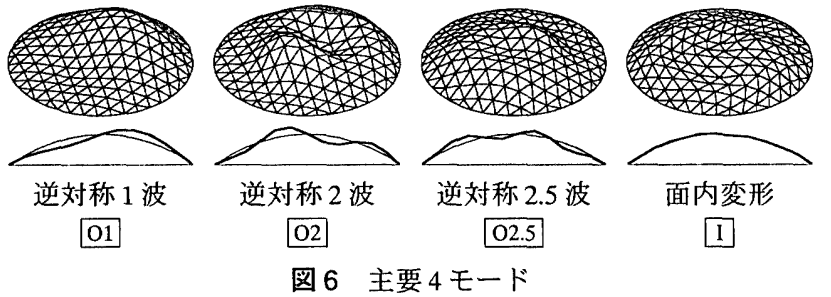

較的単純化されると考えられる。

\section{5. 下部構造の影響と応答評価}

次に, ドームの卓越モードが限定される場合を想定して, ドーム を面外剛性の高いR100相当に固定し, 下部構造の水平剛性を変化さ せた時の応答性状について検討する。3章で使用したモデルと同じ下 部構造を持つモデルを $\mathrm{F} 1$, 柱, 梁材の曲げ剛性を 0.1 倍, 10 倍, 100 倍にしたモデルをそれぞれ F0.1，F10，F100 とする。表4に，各モデ ルについて,ドーム部と下部構造の合計質量, 及び下部構造の水平剛 性を持つ 1 質点系モデルに㯰換した場合の等価固有周期 $T_{e q}$ を示す。

図 8 に, 半開角 $\theta=30^{\circ}$ の F0.1 F100 の有効質量比 $90 \%$ に必要な 固有モードを示す。ここでは, どのモデルも R100で抽出した逆対 称 1 波, 2 波, 2.5 波, 面外变形モードの主要 4 モードが主となって いる。特にF0.1では, ドーム全体が水平方向に動くスウェイにドー 厶の逆対称 1 波モードを組み合わせたモードのみが卓越する。半開 角 $\theta=20^{\circ}, 40^{\circ}$ の場合も同様の傾向を示す。そこで, 主要 4 モード のみを用いて，CQC法により応答評価することを考える。図 9 に, 有効質量比 $90 \%$ の場合と主要 4 モードのみを用いた場合の応答加 速度を示す。水平加速度, 鉛直加速度ともよく一致しており, 面外 甽性の高いモデルでは, 主要 4 モードを用いるCQC法でも, ドー ムの芯答評価が充分可能であることがわかる。以後, CQC 法は主 要 4 モードを用いて行う。

次に, 応答スペクトル法に用いる入力地震波のモデル化について検 討する。文献 10 によるレベル 1 の水平動基準応答スペクトルに文献 11 による低隇率 $D_{h}$ を乗じたモデル化加速度応答スペクトルを BRIL1 とし，図10に示す。BRI-L1 は下式で与えられる。

$$
\begin{aligned}
& S_{A}(T)= \begin{cases}200 D_{h} & (0<T<0.04) \\
200 D_{h}(T / 0.04)^{\log 3 / \log 4.5} & (0.04 \leq T<0.18) \\
600 D_{h} & (0.18 \leq T<\pi / 6) \\
100 \pi D_{h} / T & (\pi / 6 \leq T<5) \\
100 \sqrt{5} \pi D_{h} / T^{3 / 2} & (5 \leq T<10)\end{cases} \\
& D_{h}=\sqrt{\left(1+97 h_{0}\right) /(1+97 h)} \approx 1.411 \quad\left(h_{0}=0.05, h=0.02\right)
\end{aligned}
$$

ここで, $T$ は固有周期 $(\mathrm{s}), D_{h}$ は低減率, $h$ は減衰定数である。同図 中, $S_{A g}$ は入力地震波の最大加速度, $S_{A p}$ は加速度応答スペクトルの 最大值である。BRI-L1を用いて CQC 法により応答を計算した結果 を図11に示す。同図は,F10-30の稜線上節点に㧍ける応答加速度 である。BRI-L1 入力時の応答加速度は, 他の地震波入力時の応答 加速度を包絡している。これは他のモデルでも同様となっている。 以上より, 面外剛性の高いドームでは, 主要 4 モード及びモデル化 スペクトルを用いて, 各モードの応答を求め, CQC 法により合成 すれば，応答加速度を予測することが可能である。

次に, この結果を用いて, 主要 4 モードが, 各モデルの最大応答 性状にどの様な影響を与えているかを図12に示す。各図中には, 最

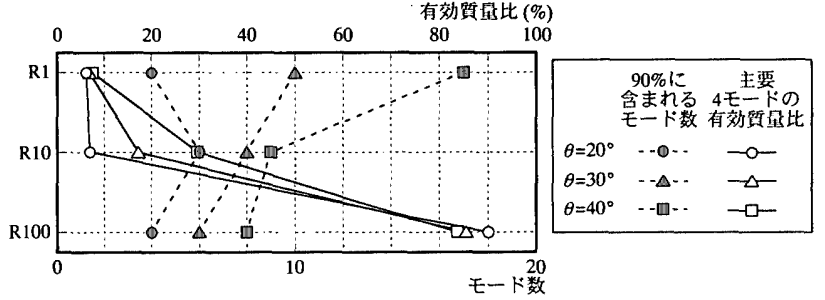

图 7 卓越モードの縮約

\begin{tabular}{|c|c|c|c|c|c|}
\hline Model & $\theta=20^{\circ}$ & $\theta=30^{\circ}$ & $\theta=40^{\circ}$ & ドーム部 & \\
\hline F0.1 & $1.155 \mathrm{~s}$ & $1.173 \mathrm{~s}$ & $1.199 \mathrm{~s}$ & & \\
\hline F1 & $0.350 \mathrm{~s}$ & $0.355 \mathrm{~s}$ & $0.362 \mathrm{~s}$ & & \\
\hline F10 & $0.111 \mathrm{~s}$ & $0.112 \mathrm{~s}$ & $0.115 \mathrm{~s}$ & 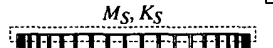 & \\
\hline F100 & $0.035 \mathrm{~s}$ & $0.036 \mathrm{~s}$ & $0.036 \mathrm{~s}$ & & 1 質点系モデル \\
\hline
\end{tabular}

表 4 下部構造の等価固有周期 $\left(T_{e q}\right)$

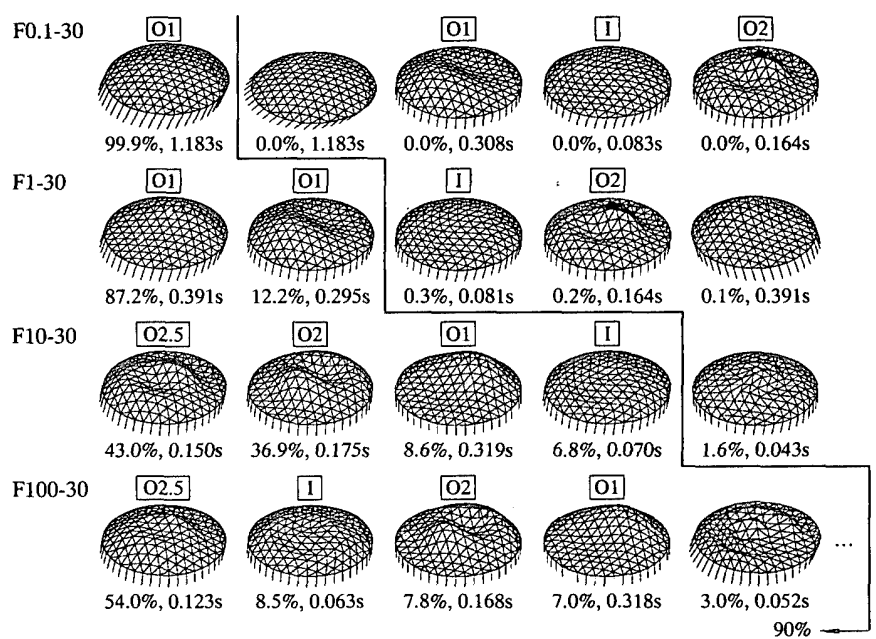

図 8 下部構造の㓮性と卓越モード $\left(\theta=30^{\circ}\right)$

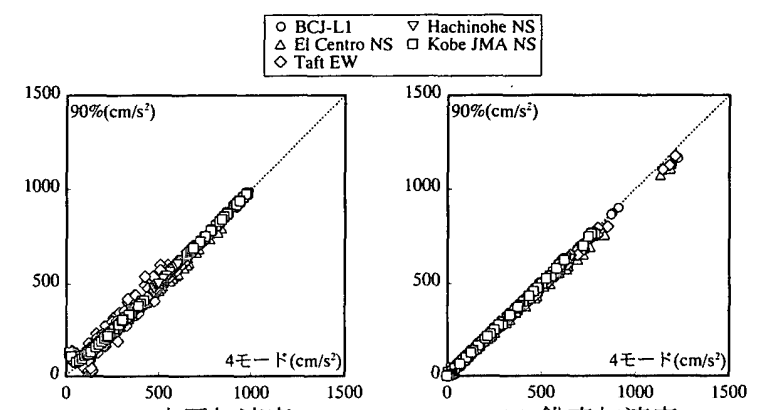

(a) 水平加速度

(b) 鉛直加速度

图 $990 \%$ と主要 4 モードの比較 $\left(\theta=30^{\circ}\right)$

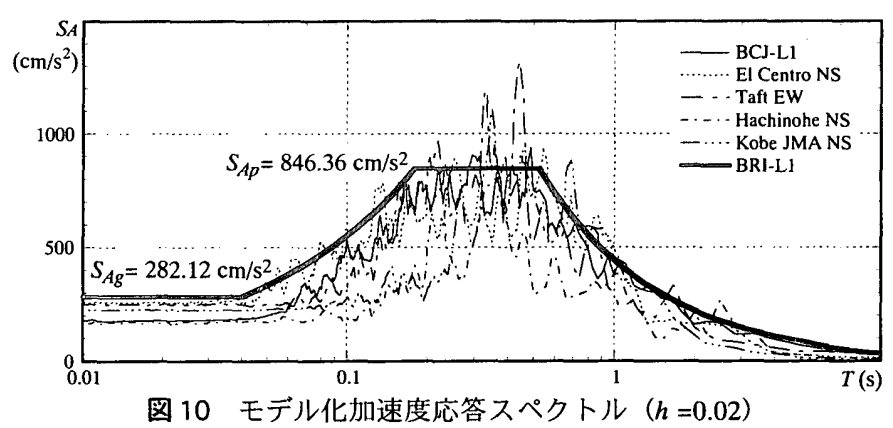




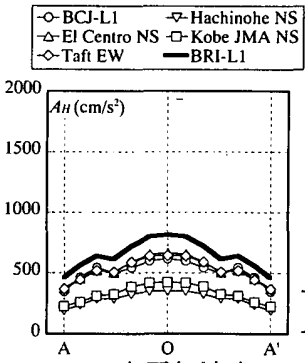

(a) 水平加速度

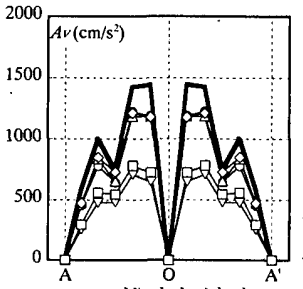

(b) 鈶直加速度

図 11 BRI-L1 の妥当性 (F10-30)

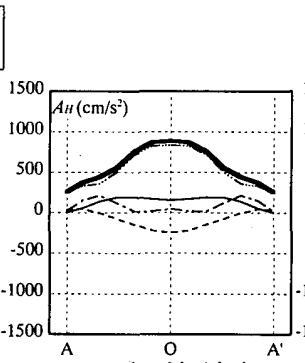

(a) 水平加速度

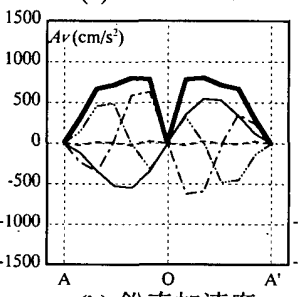

(b) 鈶直加速度

(A) R100-30

屋根モデル

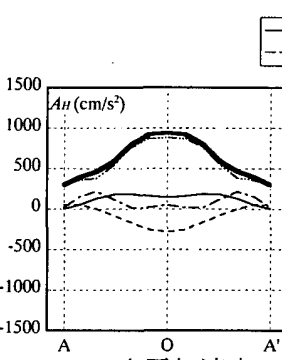

(a) 水平加速度

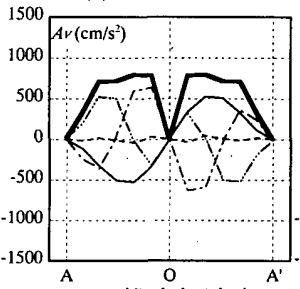

(b) 鉛直加速度

(B) $\mathrm{F} 100-30$

(屋根モード)

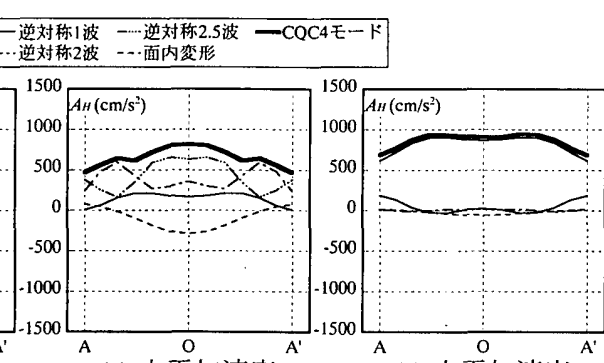

(a) 水平加速度

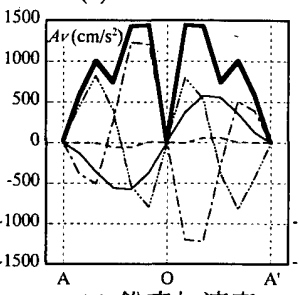

(b) 鉛直加速度

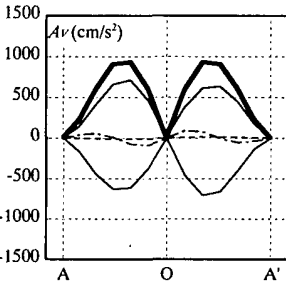

(b) 鈶直加速度 (a) 水平加速度

(C) F10-30
(連成モード)

(D) F1-30 (連成モード)

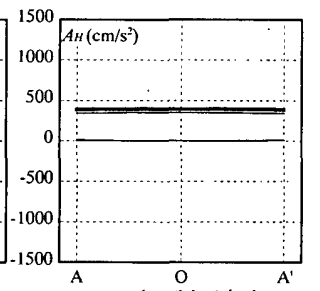

(a) 水平加速度

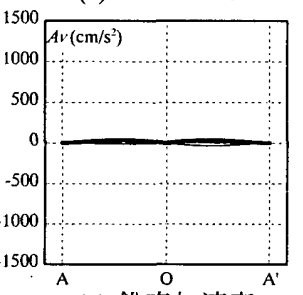

(b) 鈆直加速度

(E) F0.1-30 (スウェイモード)

\section{図 12 各モードの影響}

大応答值を太実線で, 主要 4 モードによる応答值を細線で表してい る。応答加速度の分布形状は, 下部構造の剛性により異なり, F100 では屋根モデル R100 と同じ形状，F0.1では下部構造による一様水 平応答のみとなる。卓越するモードを見ると, 水平加速度は, F100 では逆対称 2.5 波モード, F1では逆対称1波モードでほぼ決まり, F10 では 4 モードが連成している。鉛直加速度は，F100，F10では逆対

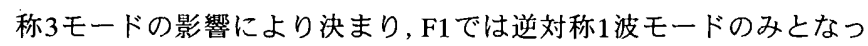
ている。これらは半開角 $\theta=20^{\circ}, 40^{\circ}$ の場合も同様の傾向である。F10

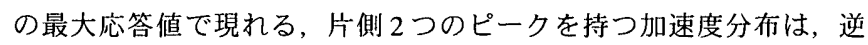
対称 2 波及び 2.5 波の合成により構成されていることがわかる。

次に, ドーム部と下部構造の関係を明確にするため, 山田4)のス タディに今回のモデルを当てはめ, 全体モデルを図 13 に示すよう な,ドーム部と下部構造の質量及び剛性からなる2質点系モデルに 置き換える。 $M_{D}, M_{S}$ はそれぞれドーム部, 下部構造の質量であり， $K_{D}, K_{S}$ はドーム部, 下部構造の剛性である。また, 2 質点系モデル の 1 次, 2 次固有周期を $T_{1}, T_{2}$ とすると, 固有円振動数 $\omega_{1}, \omega_{2}$ は 下式で表せる。

$$
\left\{\begin{array}{l}
\omega_{1} \\
\omega_{2}
\end{array}\right\}=\sqrt{\frac{R_{M}\left(1+R_{T}^{2}\right) \mp \sqrt{R_{M}^{2}\left(1+R_{T}^{2}\right)^{2}-4 R_{M}^{3} R_{T}^{2} /\left(1+R_{M}\right)}}{2 R_{M}^{2} R_{T}^{2} /\left(1+R_{M}\right)}} \omega_{D}
$$

なお, 質量比 $R_{M}=M_{S} / M_{D}$, 周期比 $R_{T}=T_{e q} / T_{D}$ であり, $T_{e q}$ は 1 質点系 モデルの等価固有周期, $T_{D}, \omega_{D}$ は屋根のみのモデルの固有周期及 び固有円振動数である。

図 14 に質量比 $R_{M}$ 及び周期比 $R_{T}$ を変化させた場合の $\omega_{1} / \omega_{2}$ 分布を 示す。本論文で検討しているモデルは, 屋根のみを支持する下部構造 を想定しているため, 質量比 $R_{M}=0.2$ 程度之小さく, 図 14 の範囲の中 で, 下部構造による上部の增幅効果が比較的小さい範囲に位置する。

図 15 に $\omega_{1} / \omega_{D}$ と $R_{T}$ の関係を示す。同図中に主要 4 モードをプ ロットしており, 各モデルとも周期比 $R_{T}$ の小さい方からドーム部 の固有周期 $T_{D}$ が，逆対称 1 波， 2 波， 2.5 波，面内変形モ一ドの周 期となっている。また，黒鉒りのプロットは有効質量比が $1.0 \%$ 未 満となるモードである。逆対称 1 波モードが $R_{T}<0.2$ 程度の範囲に

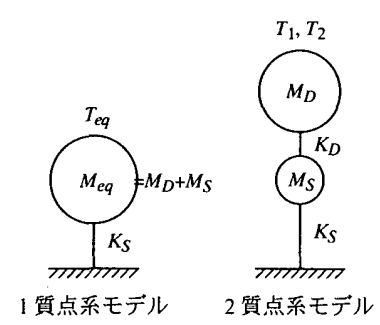

図 13 2質点系モデルへの置換

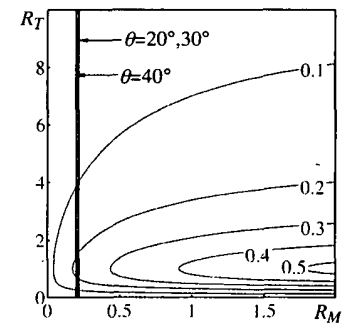

図 14 上下連成度 $\left(\omega_{1} / \omega_{2}\right)$
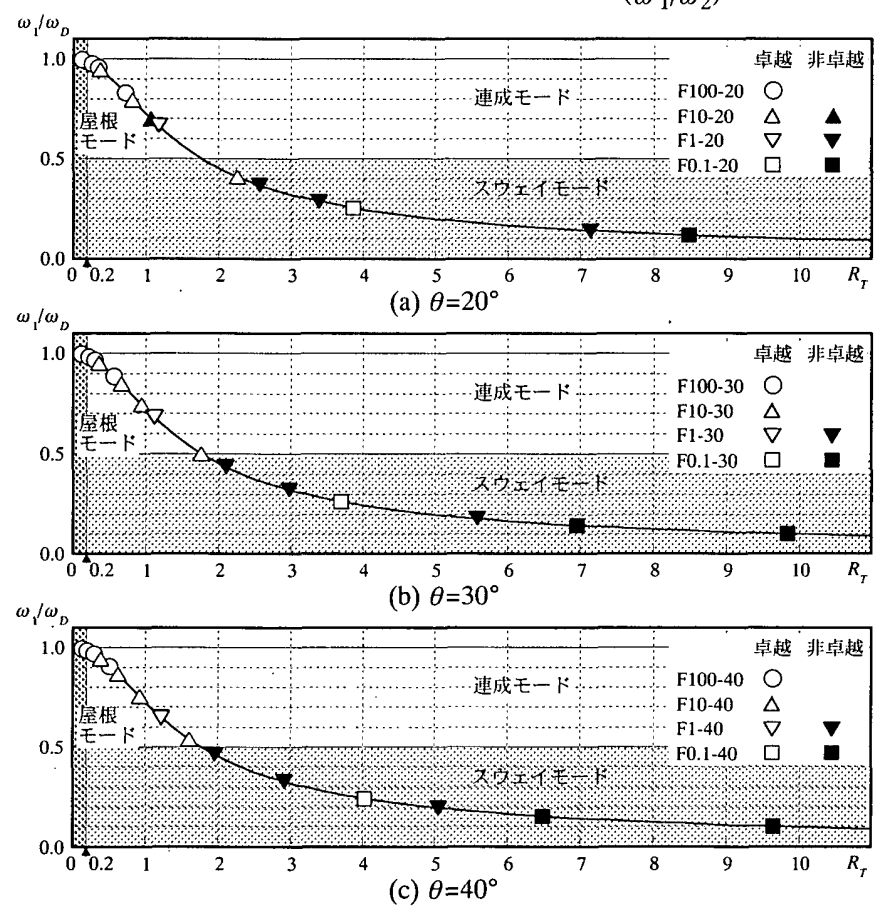

図 $15 \quad \omega_{1} / \omega_{D}-R_{T}$ 関係

あるモデルは, 下部構造の剛性が充分高く,ドーム部の卓越モード は, 屋根のみのモデルのモードとほぼ同じになる。また, $\omega_{1} / \omega_{D}<0.5$ 程度の範囲では, 下部構造の剛性が低く,ドーム部全体が水平移動 するため, 下部のスウェイとドーム部の逆対称 1 波モードを組み合 


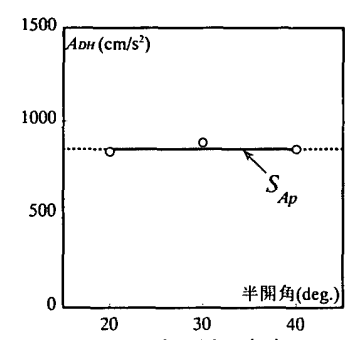

(a) 水平加速度

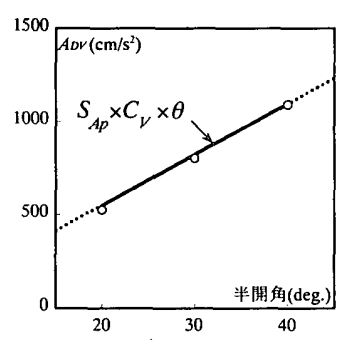

(b) 鉛直加速度
図 16 最大応答加速度（R100）
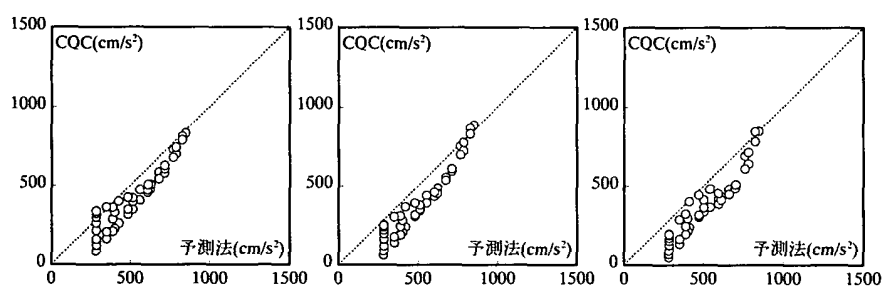

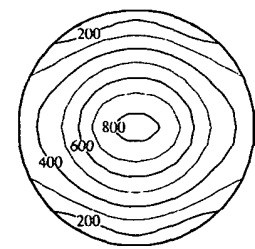

$\mathrm{COC}$

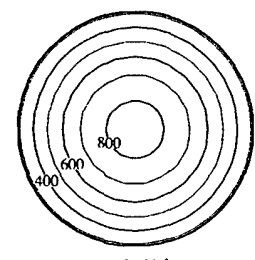

予測法

(a) R100-20

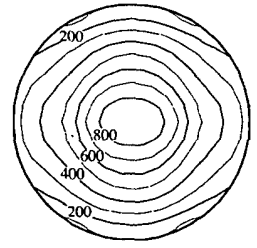

CQC

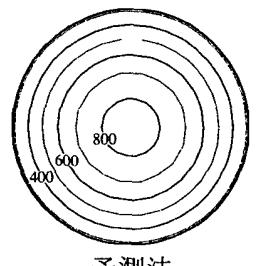

予測法

(b) R100-30

(A) 水平加速度
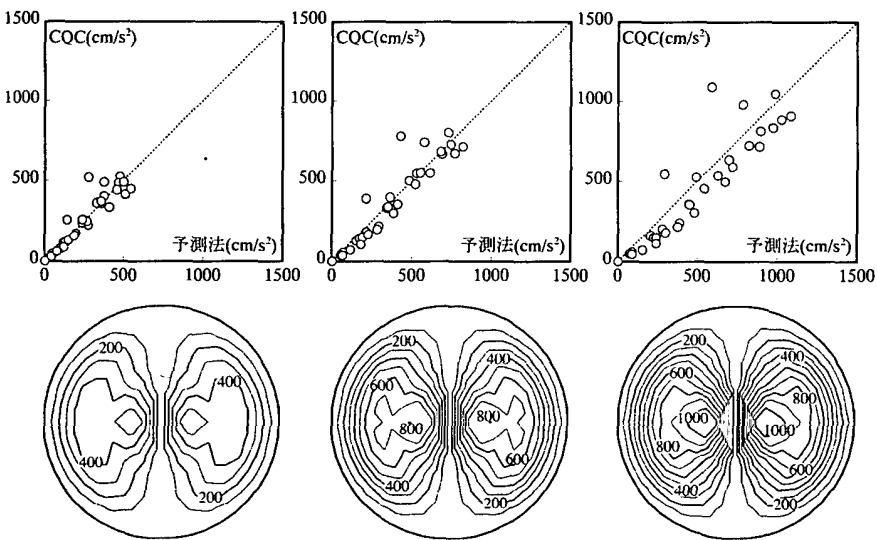

$\mathrm{CQC}$

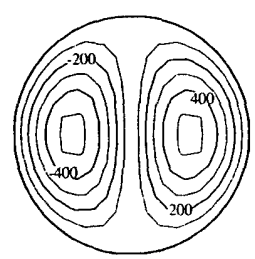

予測法

(a) R100-20

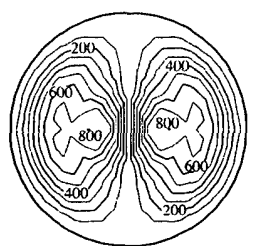

$\mathrm{CQC}$

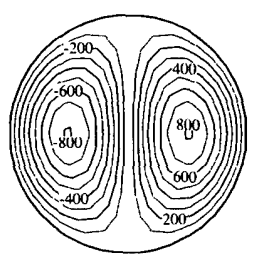

予測法

(b) R100-30

(B) 鉛直加速度

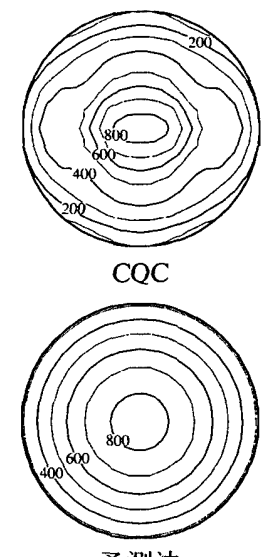

予測法

(c) $\mathrm{R} 100-40$

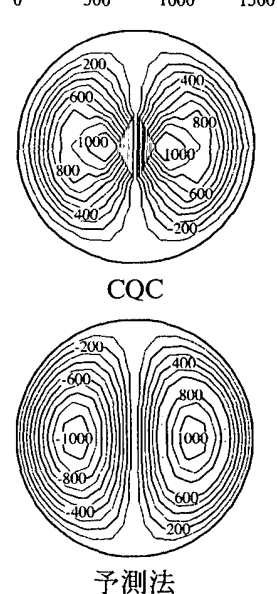

(c) R100-40

图 $17 \mathrm{CQC}$ 法による加速度分布と予測法による加速度分布の比較

わせたモードのみが卓越している。これらの中間に位置する範囲 は, 下部構造とドームが連成し, ドーム部の応答が下部構造の影響 で增幅する領域となっている。

\section{6. 最大応答加速度の予測}

以上より,ドーム部の面外剛性が高い場合には, 主要な数モード とモデル化スペクトルを使用し， CQC 法等の応答スペクトル法を 用いれば, 分布形状を含めた応答加速度予測が可能であり，下部構 造による影響もドーム部との質量比及び周期比の関係により分類で きることがわかった。しかし，主要モードを求めるには，やはり固 有值解析が必要であり，主要モードより合成された最大応答を，大 まかであっても単純な関数で近似できると,設計上の有効範囲が広 い。そこで, 以降淂られた特性を利用し, 静的地震荷重の設定方 法について考える。

まず, 下部構造の無い屋根モデルの最大応答加速度分布の近似関 数を検討する。R100における BRI-L1 入力時の水平及び鉛直加速 度の最大值と半開角の関係は, 図 16 に示すとおりである。水平加 速度の最大值は, 半開角に依らずほぼ一定であり,これは, 加速度 応答スペクトルの最大值 $S_{A p}$ (図 10) に対応している。また，鈶直 加速度の最大值は, 半開角が大きくなるにつれて増大し，ほほ比例 関係 $S_{A p} \times C_{\nu} \times \theta$ となっている。ここで $C_{\nu}$ は定数であり，本論文の検 討モデルでは $C_{V}=1.85$ となっている。また $\theta$ の単位は $\mathrm{rad}$ である。 そこで, 屋根モデルの最大応答加速度分布を文献 2 を参考に, 以下
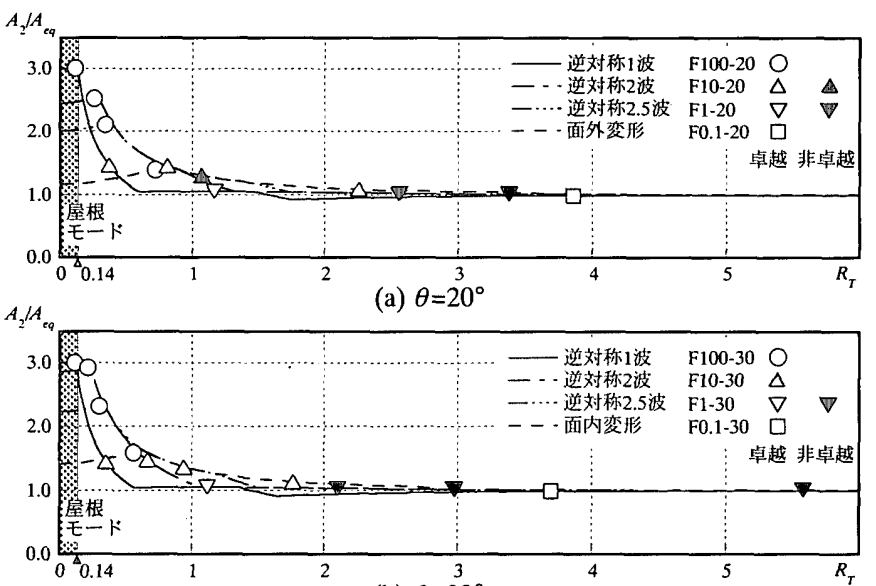

(b) $\theta=30^{\circ}$

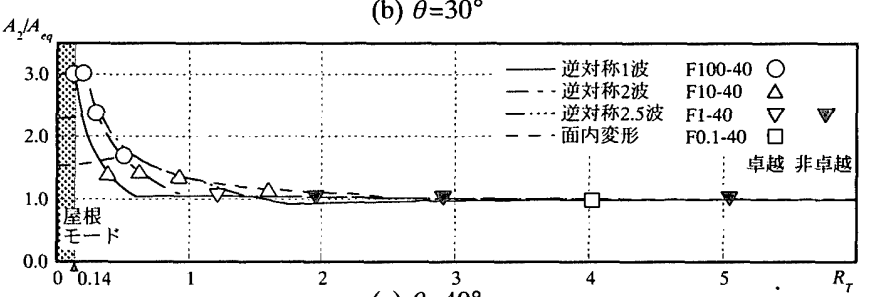

(c) $\theta=40^{\circ}$

图 $18 A_{2} / A_{e q}-R_{T}$ 関係

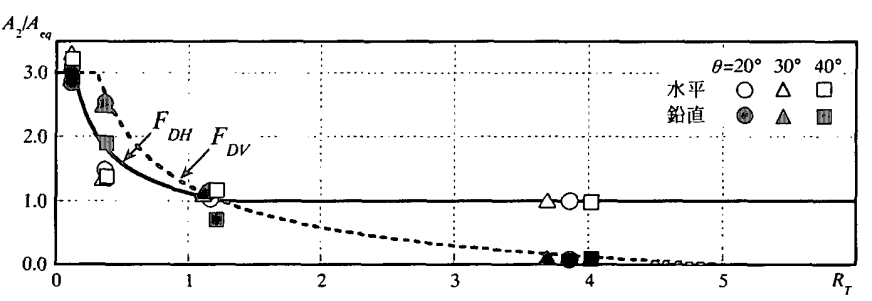

図 19 ドームの応答増幅率 
のように設定する。

$$
\text { 水平: } A_{D H}(x, y)=S_{A g}\left\{1+\left(\frac{S_{A p}}{S_{A g}}-1\right) \cos \frac{\pi \sqrt{x^{2}+y^{2}}}{L}\right\}
$$

鉛直: $A_{\nu v}(x, y)=S_{A \nu} C_{V} \theta \frac{x}{\sqrt{x^{2}+y^{2}}} \sin \frac{2 \pi \sqrt{x^{2}+y^{2}}}{L}$

ここで, $S_{A g}$ は入力加速度の最大值 (図 10), L はドームのスパンで ある。CQC 法による応答加速度と，(8)，(9)式で表される応答加速 度の比較及び分布図を図 17 に示す。複数モードの合成による応答 を水平は対称, 鉛直は逆対称波の関数で近似しているため, 加速度 が最大となる節点が多少異なってはいるが，CQC 法による応答加 速度と, (8), (9)式による応答加速度は概ね良い対応を示している。

次に, 下部構造付モデルの最大応答加速度分布について検討する。 ドーム部と下部構造の連成振動による応答への影響は, 周期比 $R_{T}$ の 関数として評価できる。そこで，4章で検討した BRI-L1 入力時の 2
質点系モデルの上層の応答增幅率 $A_{2} / A_{e q}$ を図 18 に示す。ここで, $A_{2}$ は2質点系モデルの上層の応答加速度, $A_{e q}$ は 1 質点系モデルの応答 加速度である。同図中に主要 4 モードをプロットしており, 各モデ ルとも周期比 $R_{T}$ の小さい方からドーム部の固有周期 $T_{D}$ が, 逆対称 1 波, 2 波, 2.5 波, 面内変形モ一ドの周期となっている。また, 黒 塑りのプロットは有効質量比が $1.0 \%$ 末満となるモードである。全体 の傾向は，モデル及びモードに依らず類似しており, 逆対称1波モ一 ドが $R_{T}<0.14$ 範囲にあるモデルの逆対称 1 波モードの応答增幅率は $A_{2} / A_{e q}=3.0$ となっている。これは, 屋根モデルの応答増幅率, 即ち $S_{A p} / S_{A g}$ に対応していると考えられる。また, 周期比 $R_{r}>1$ 程度の範囲 では $A_{2} / A_{e q}=1.0$ となり, 上層の応答の增幅は見られない。

次に，全体モデルの応答增幅率を下式のように定義する。

水平: $A_{2} / A_{e q}=A_{H \max } / A_{e q}(10)$ 鉛直: $A_{2} / A_{e q}=A_{V \max } / C_{V} \theta A_{e q}$ (11) ここで, $A_{H \max }, A_{V_{\text {max }}}$ はドーム部節点の水平及び鉊直応答加速度の

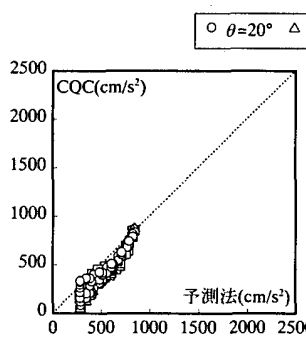

(a) R100

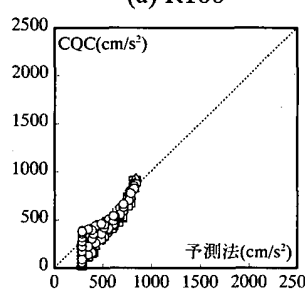

(b) F100

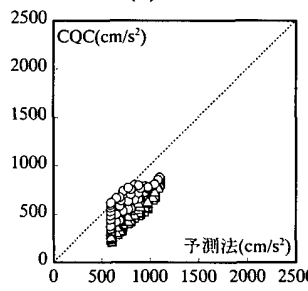

(c) F10

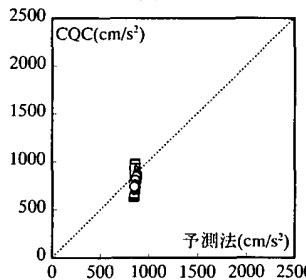

(d) F1

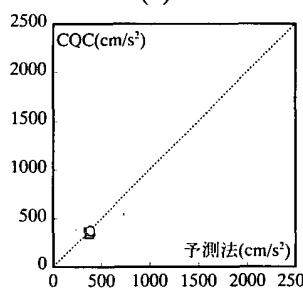

(e) F0.1

(A) 水平加速度

図 20 予測法による加速度

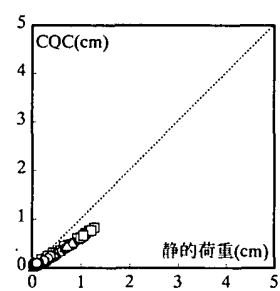

(a) R100

(a) R100

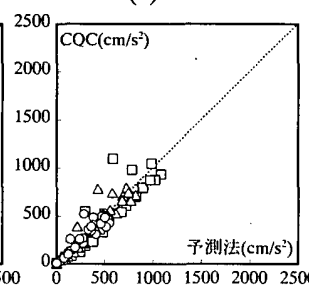

(b) F100

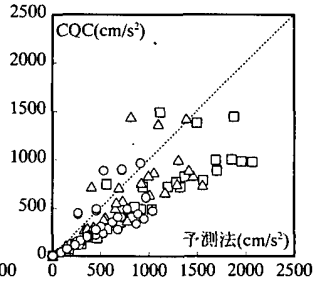

(c) F10

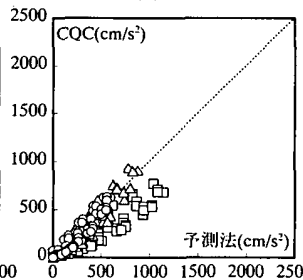

(d) F1

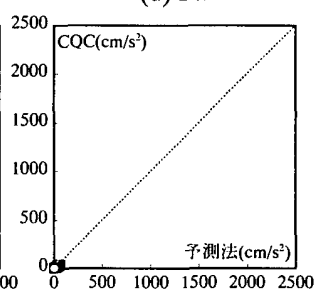

(e) F0.1

(B) 鉛直加速度

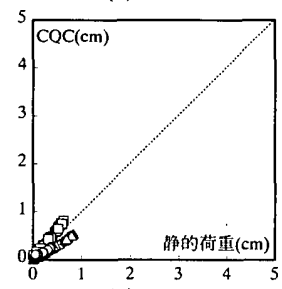

(b) F100

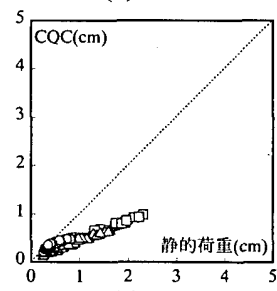

(c) F10

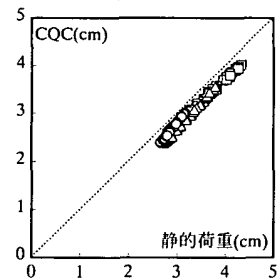

(d) F1

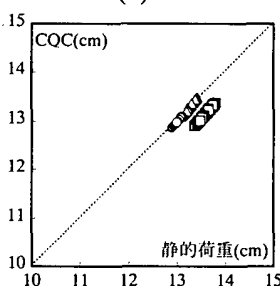

(e) F0.1

(A) 水平変位

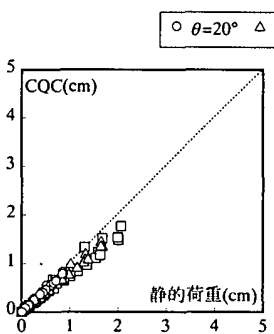

(a) R100

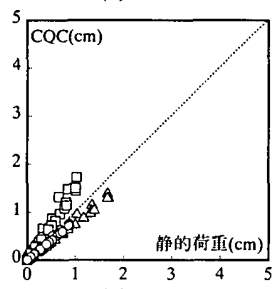

(b) F100

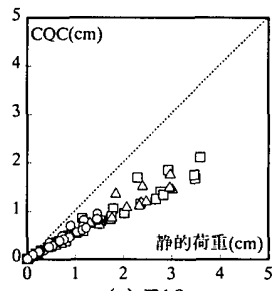

(c) F10

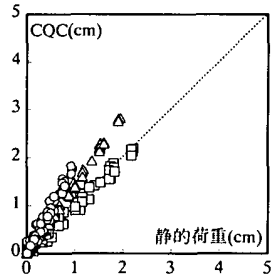

(d) F1

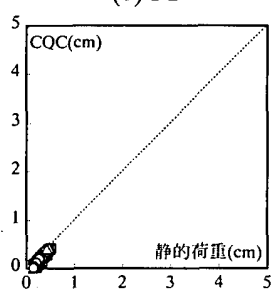

(e) F0.1

(B) 鉛直変位

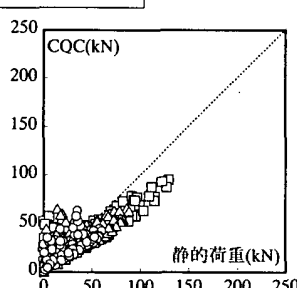

(a) R100

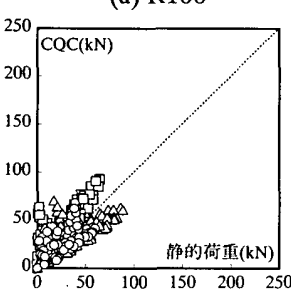

(b) F100

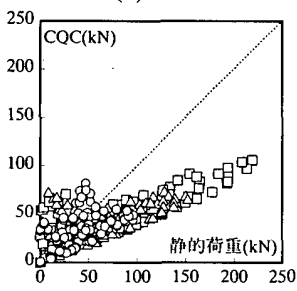

(c) F10

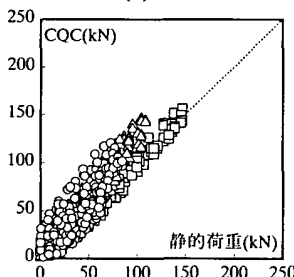

(d) F1

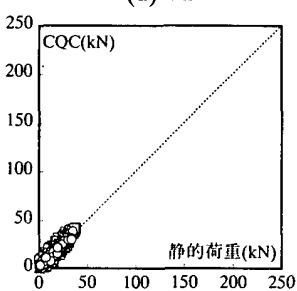

(e) F0.1

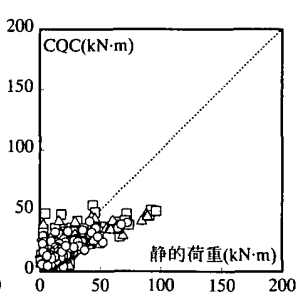

(a) R100

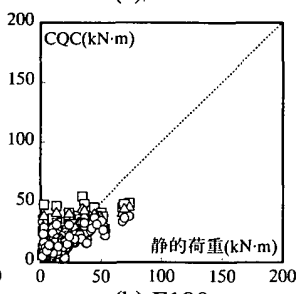

(b) F100

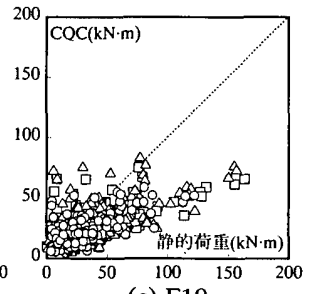

(c) F10

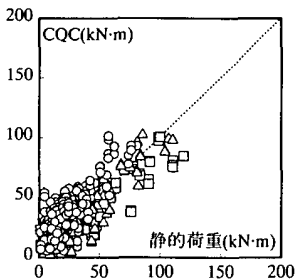

(d) F1

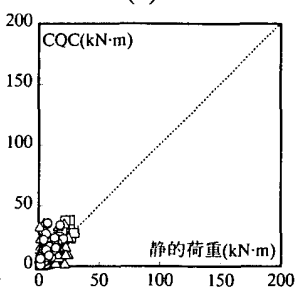

(e) F0.1

図 21 予測法による加速度を静的荷重とした場合の精度 
最大値である。(10), (11)式より求めた下部構造付モデルのドーム 部の応答增幅率を, 逆対称 1 波モードの周期比 $R_{T}$ に対してプロッ トしたものを図 19 に示す。全体モデルと 2 質点系モデルの応答增 幅率は同様の傾向となっている。これらの応答増幅率を周期比 $R_{T}$ の関数 $F_{D H}, F_{D V}$ として表現すると, (8), (9) 式より, ドーム部の 最大応答加速度分布は，下式のように設定できる。

$$
\begin{aligned}
& \text { 水平: } A_{l l}(x, y)=A_{e q}\left\{1+\left(F_{D I I}-1\right) \cos \frac{\pi \sqrt{x^{2}+y^{2}}}{L}\right\} \\
& \text { 鉊直: } A_{v}(x, y)=A_{e q} F_{D V} C_{v} \theta \frac{x}{\sqrt{x^{2}+y^{2}}} \sin \frac{2 \pi \sqrt{x^{2}+y^{2}}}{L}
\end{aligned}
$$

但し, ドーム部の応答増幅率は, 図 19 より,

$$
\begin{aligned}
\text { 水平: } F_{D H}= \begin{cases}3 & \left(0<R_{T} \leq 5 / 36\right) \\
\sqrt{5 / 4 R_{T}} & \left(5 / 36<R_{T} \leq 5 / 4\right) \\
1 & \left(5 / 4<R_{T}\right)\end{cases} \\
\text { 鉛直: } F_{D V}= \begin{cases}3 & \left(0<R_{T} \leq 5 / 16\right) \\
\sqrt{5 / R_{T}}-1 & \left(5 / 16<R_{T} \leq 5\right) \\
0 & \left(5<R_{T}\right)\end{cases}
\end{aligned}
$$

なお, $F_{D H}, F_{D V}$ は本来 $R_{T}$ 及び $R_{M}$ の関数であり，(14), (15) 式は今回 検討した $R_{M}=0.2$ に対応した関数であることに留意する必要がある。

以上より, 今回対象としたデプス/スパン比 1/50程度の中規模ラ チスドームの地震応答加速度を, 以下に示す過程で求めることが可 能となる。

1) ドーム部と下部構造を一体とみなして等価固有周期 $T_{e q}$ を計算

し, 応答加速度 $A_{e q}$ を求める。

2) ドーム部の逆対称 1 波モードの固有周期 $T_{D}$ と等価固有周期 $T_{e q}$ と の周期比 $R_{T}$ を求める。

3) (14), (15) 式により, ドーム部の応答増幅率 $F_{D H}, F_{D V}$ を求める。 4) (12), (13) 式により, ドーム部の応答加速度 $A_{H}, A_{V}$ を求める。 上記の過程において, ドーム部の逆対称 1 波モ一ドの固有周期 $T_{D}$ が末知となるが，これはデプス/スパン比と半開角 $\theta$ の関数になっ ていると考えられる。本論文では, デプス/スパン比 $1 / 50$ 程度の検 討モテルルおいて, 半開角 $\theta$ にる変動は土5\%程度しかないので, 3 モデルの平均値 $T_{D}=0.305 \mathrm{~s}$ で一定と仮定し評価することにする。 以上の手続きにより求められた $A_{H}$ 及び $A_{V}$ と $\mathrm{CQC}$ 法による最大応 答加速度を比較したものを図 20 に示す。 $F_{D H}$ 及び $F_{D v}$ の関数設定条 件より，F10の応答予測法による加速度が大きめになっているが， $A_{H}$ 及び $A_{V}$ は概刘対応していると言える。

この応答予測法で求めた $A_{H}$ 及び $A_{V}$ と質量の積を静的地震荷重と して載荷した場合の変位及び部材応力を図 21 に示す。加速度と同 様, $F_{D H}, F_{D v}$ を大きめに設定している F10では, 変位及び部材応力 はやや安全側に振れる。一方, 図21(C)(D)では部材応力のばらつき が比較的大きいが，これは 3 章で検証した様に，最大加速度をその まま地震荷重係数としたことによる誤差と考えられる。従って, 部 材設計においては, 最大応力で照査した部材と同断面の部材をある 程度広い範囲で使用するなどの措置が必要となると思われる。

\section{7. 結}

下部構造に支持されたスパン $60 \mathrm{~m}$ の中規模ラチスドームの半開 角, 面外剛性及び下部構造の剛性を変化させたモデルについてパラ メトリックスタディを行い, 上記指標と卓越する振動モードとの関 係を分析した結果，以下の点が明らかになった。
1) 下部構造の無い屋根のみの主要な振動モードは, 面外剛性が高く なるにつれて限定され，デプス/スパン比が $1 / 50$ 程度では，半開 角に関わらず，逆対称 1 波， 2 波，2.5 波，面内変形の 4 モ一ドで 有効質量比 $80 \%$ 以上を占める。

2) 下部構造を有する上記条件下のドームの応答は,ドーム部と下部 構造を一体と考えた等価 1 質点系固有周期とドーム自身の主要 モード周期帯との関係により規定される。ドームの逆対称 1 波 モード周期に対する等価 1 質点系周期の比が 0.14 以下では, 下部 構造の無い屋根のみの振動モードと同等となる。また,ドームの 逆対称 1 波モードの固有円振動数に対する, ドームと下部構造か らなる 2 質点系 1 次固有冈振動数の比が約 0.5 以下では, ドーム 全体が下部構造でスウェイする振動モ一ドのみが支配的となる。

3) 2) で示した両者の中間範囲では, ドームと下部構造が連成振動 するが, 下部構造とドームの主要4モードにより表現が可能であ る。具体的には, 主要 4 モードに CQC 法を適用して応答特性を 表現できる。

4) 屋根のみの主要モードによる応答加速度分布を包絡する近似関数 を設定できれば，これにデプス/スパン比の影響，及びドーム部 と下部構造の周期比による増幅率を加味した, 応答加速度評価式 が設定できるものと思われる。但し，これを静的地震荷重として 部材設計を行う場合には, 適切な措置が必要であると考えられる。 なお, 今回の検討は, 限られた䇶囲のモデルに抛っているため, 特に 4)の応答加速度評洒手法については，異なる規模，質量比の ドームに適用した場合の精度についての検証を行う必要があると思 われ，今後の課題としたい。

\section{謝辞}

本研究の一部は, 平成 15 年度科学研究費補助金基盤研究 (C)(2) （課題番号 : 14550560）によるものである。ここに謝意を表します。

\section{参考文献}

1) 加藤史郎, 小西克尚, 中澤祥二, 向山洋一, 打越瑞昌 : 下部構造に支持された空 間構造の振動解析用質点簡易モデル，構造工学論文集, Vol.48B, pp.37-47, 2002.3 2）加藤史郎，小西克尚：ラチスドームの Push-over analysis に基づく地震応答推 定に関する一考祭ー1次モ一ド支配型の空間構造に対する检討一，日本建築学 会構造系諭文集，第 561 号, pp.153-160, 2002.11

3）小西克尚，加藤史郎，中澤祥二，倉本洋：ラチスドームのPush-over analysisに 基づく地震忘答推定に関する一考察一2つのモードが支配的な空間構造物に対 する検討一，日本建築学会構造系論文集，第 569 号，pp.89-96，2003.7

4) 山田大彦 :空間構造の地震応答に及ぼす下部構造の影響に関する初歩的考察, 第 10 回「シェル・空間構造」セミナ一資料, 日本建築学会構造委員会 シエ ル・空間構造運営委員会; pp.65-77, 2001.11

5) E. L. Wilson, et al. : Short Communications A Replacement for the SRSS Method in Seismic Analysis, Earthquake Engineering and Structural Dynamics, Vol.9, pp.187-194, 1981

6) 小河利行, 中川美香, 熊谷知彦:応答スペクトル解析を用いた単層ラチスドー 厶の地震応答解析，構造工学論文集，Vol.49B，pp.291-296，2003.3

7) T. Ogawa, T. Takeuchi, M. Nakagawa, T. Kumagai : Seismic Response Analysis of Single Layer Lattice Domes with Substructure, IASS-APCS Int.Symposium Proceedings, pp.110-111, 2003.10

8) 渡辺基史, 潼澤春男: モ一ド別単振子の時刻歴応答間に見られる相関度，日本 建贸学会大会学術講演梗概集 (東海)，構造 I, pp.743-744, 1994.9

9）大網浩一：CQC 法におけるモード相関係数の簡便な近似式とその適用例，日 本建築学会構造系論文集, 第 515 号, pp.83-89, 1999.1

10) 建設省建築研究所 : 建築研究資料 第 83 号 設計用入力地震動作成手法, 1994.11

11) 笠井和彦, 伊藤浩資, 渡辺厚 : 等価線形化法による一質点弾塑性構造の最大态 答予测，日本建築学会構造系論文集，第 571 号，pp.53-62，2003.9

(2003年12月 10 日原稿受理， 2004 年 2 月 16 日採用決定） 